\title{
Preliminary data on the occurrence of marine turtles in the Laje de Santos Marine State Park (SP, Brazil)*
}

\author{
Ana Carolina Luchetta ${ }^{1,2 * *}$, Luciana Erika Yaginuma Watanabe ${ }^{2}$
}

1 UNESP - Campus do Litoral Paulista

(Praça Infante Dom Henrique s/nº São Vicente - SP - 11330900 - Brazil)

2 FUNDESPA

( Av. Afrânio Peixoto, 412 - Butantã, São Paulo - SP - 05507000 - Brazil)

** Corresponding author: anacarolluch@gmail.com

\section{Abstract}

Although marine turtles have always been observed by divers, there are few scientific works on marine turtles in the Laje de Santos Marine State Park (PEMLS). Diurnal (bimonthly) and nocturnal (biannual) surveys were conducted between 2013 and 2015 for a more comprehensive study, totalizing 42 hours of diurnal observations and the capture of 41 turtles during nocturnal dives. During the diurnal surveys, visual observations were made from two land based sites (Paredão da Face Sul and Portinho). The numbers of heads (heads observed whether they are of the same turtle or not) and turtles (individuals observed in groups) were counted. The results showed the presence of marine turtles throughout the year. More turtles were observed from Paredão da Face Sul than from Portinho, the latter being a more sheltered point and a site preferred by divers. The nocturnal surveys consisted of the capture of turtles through scuba diving so they could be measured and weighed and tagged according to the guide-lines of the TAMAR project. Four nocturnal surveys were conducted and in the last survey three tagged turtles were captured, two of them having been tagged during this study. The measurements of these turtles indicated their growth during the study period.The present survey also highlighted the importance of the PEMLS as a feeding area for juvenile marine turtles.

Descriptors: Observation; Land Based Survey; Capture and Recapture; Biometry; Marine Turtle; Laje de Santos.

Received: June 2, 2017

Approved: August 11, 2017

* Paper presented in the International Sandy Beach Symposium, 7. 2015, Ilhabela, São Paulo, Brazil .

\section{Resumo}

Apesar de serem muito observadas por mergulhadores, poucos trabalhos científicos foram realizados com as tartarugas marinhas no Parque Estadual Marinho da Laje de Santos (PEMLS). No período entre 2013 e 2015 campanhas diurnas e noturnas foram realizadas para maior abrangência deste estudo, totalizando 42 horas de observações e 41 tartarugas capturadas em mergulhos noturnos. Nas campanhas diurnas foram realizadas observações em dois pontos fixos: Paredão da Face Sul e Portinho. Foram contabilizadas as cabeças (número de cabeças observadas, independentemente de serem do mesmo animal ou não) e tartarugas (indivíduos únicos, geralmente observados em grupos). De acordo com os resultados, pôde-se notar a presença de tartarugas marinhas ao longo de todo o ano. Foram observados mais tartarugas no lado do Paredão da Face Sul do que no Portinho, sendo este último ponto mais abrigado e local de preferência dos mergulhadores. Já as campanhas noturnas consistiram na captura de tartarugas através de mergulho autônomo para que as mesmas fossem medidas, pesadas e anilhadas conforme orientação do Projeto TAMAR. Foram realizadas quatro campanhas noturnas, sendo que na última campanha, houve captura de três tartarugas anilhadas, incluindo dois exemplares previamente marcados pela nossa equipe. Os resultados indicaram crescimento das tartarugas no período de estudo. O presente levantamento evidenciou a elevada importância do PEMLS como área de alimentação de tartarugas marinhas juvenis.

Descritores: Observação, Ponto Fixo, Captura e Recaptura, Biometria, Tartaruga Marinha, Laje de Santos.

http://dx.doi.org/10.1590/S1679-87592017144006504 


\section{INTRODUCTION}

Five of the seven species of marine turtles existing in the world occur on the Brazilian coast (MARCOVALDI \& MARCOVALDI, 1999): loggerhead (Caretta caretta), green turtle (Chelonia mydas), leatherback (Dermochelys coriacea), hawksbill (Eretmochelys imbricata) and olive ridley (Lepidochelys olivacea). All the species occurring in Brazil are considered endangered or vulnerable, according to international (IUCN, 2016 and UNEP-WCMC, 2015) and national (MMA, 2003) lists of threatened species, and their capture is prohibited. However, many are the victims of direct human impacts such as the illegal capture and removal of eggs from the nests for human consumption, besides the incidental capture by fishing nets. Furthermore, these animals still suffer from indirect impacts like pollution, urbanization, beach occupation (MÁRQUEZ, 1990; AWABDI et al., 2013) and marine navigation.

Sea turtles use the coast of the state of São Paulo (southeastern coast of Brazil) as a feeding area (SAZIMA \& SAZIMA, 1993; MARCOVALDI \& MARCOVALDI, 1999; GALLO et al., 2006; STAMPAR et al., 2007). In the Baixada Santista, a metropolitan area located on the coast of São Paulo state, the occurrence of sea turtles is commonly described by residents, tourists and fishermen. Accidental and intentional capture by fishing nets and hooks is also reported, as well as the appearance of carcasses on the beaches of the region. Previous studies have recorded the presence of marine turtles in the Bay of São Vicente (ABESSA et al., 2005; 2007), with frequent sightings on beaches and even in the internal areas of the estuary. Besides these coastal areas, the occurrence of marine turtles is also common around more offshore islands, like those of the Laje de Santos Marine State Park (PEMLS) region.

The PELMS is located off the southeastern coast of Brazil, in the Santos Basin, a region well known for its petroleum and gas exploration. The park was created due to its extraordinary diversity and abundance of marine life and scientific value. Its ecological importance extends beyond its geographical borders since various marine species, which migrate along the Atlantic coast, use this region as a feeding, breeding and growing area. Furthermore, its natural underwater beauty has made the Laje de Santos a traditional diving site on the Brazilian coast. It was because of the ongoing rapid degradation of the biota, due to activities such as trawling, predatory spearfishing and the capture of fish and marine invertebrates for ornamental trades, that this conservation unit was created (SÃO PAULO, 1993).

Marine turtles has been observed in the PEMLS region by divers, but no previous studies have been undertaken. This study aimed to present preliminary data on the marine turtles that frequent the PEMLS. These data can then be use in the first analysis of the marine turtles of the park.

\section{MATERIAL AND METHODS STUdy Area}

The Laje de Santos Island is located in the continental shelf in the southeastern coast of Brazil, $40 \mathrm{~km}$ from the city of São Vicente and about $120 \mathrm{~km}$ from São Paulo (Figure 1) in the coordinates $24^{\circ} 19^{\prime} 18^{\prime \prime} \mathrm{S} / 46^{\circ} 10^{\prime} 57^{\prime \prime} \mathrm{W}$. The PEMLS is the first and only marine park among the Conservation Units of the state of São Paulo. The park is a Full Protection Unit category of the National System of Nature Conservation Units (SNUC) and a Protected Area of Category II according to the IUCN (International Union for Conservation of Nature), which allows the development of scientific research, educational and recreation activities. It was created on September 27, 1993, by State Decree $\mathrm{n}^{\circ} 37,537$, and has an area of 5,000 ha that includes the Laje de Santos Island (with $33 \mathrm{~m}$ altitude, $550 \mathrm{~m}$ long and 185 $\mathrm{m}$ wide), other rocky outcrops (Calhaus) and various submerged rocks (Parcéis do Bandolim, do Brilhante, do Sul and Novo) (SÃO PAULO, 1993). All these rocky formations provide a hard substrata for the development of macroalgae, therefore creating a habitat that supports a diversity of marine organisms, including sea turtles. 


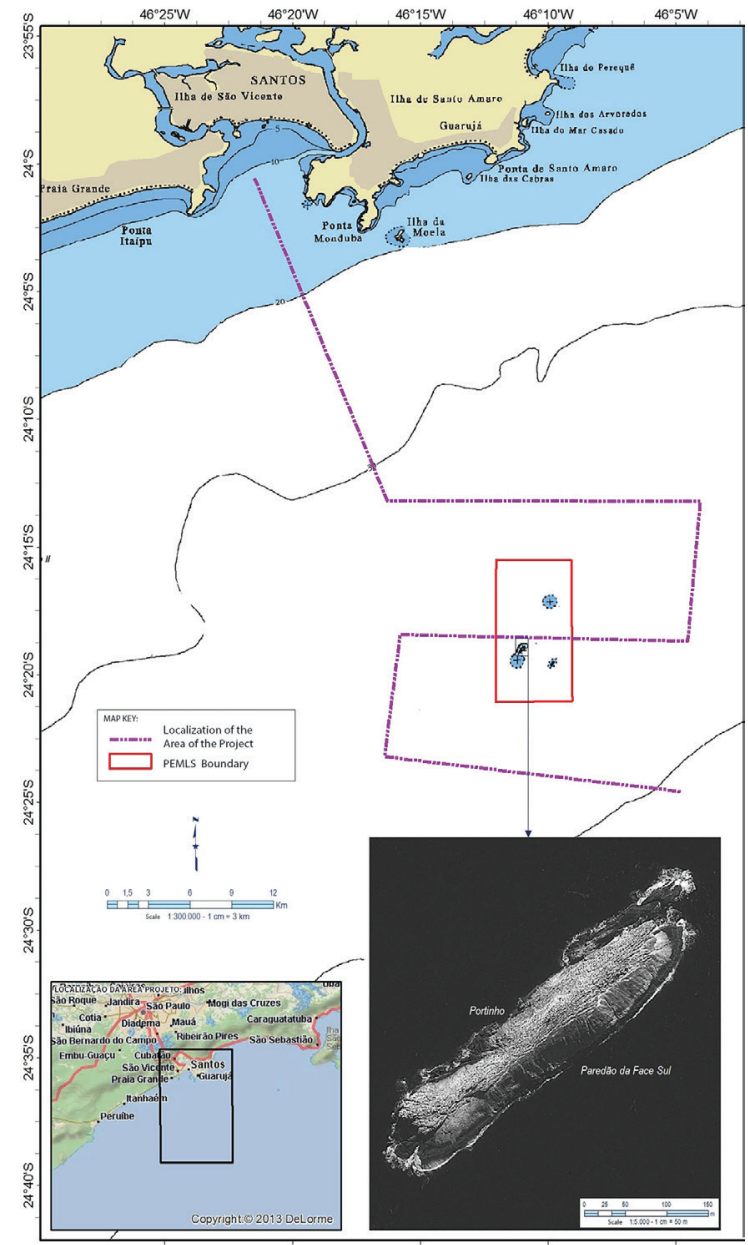

Figure 1. Location of the PEMLS area (red box) on the continental shelf off the state of Sao Paulo, with the route taken by the vessel during the pilot campaign (purple line), highlighting the Laje de Santos Island.

The Laje de Santos Island has an elongated shape, with the two longer sides facing north and south. The north side is known and frequented by certified divers as Portinho site. This point is more sheltered from currents and depths reach $22 \mathrm{~m}$. The Paredão da Face Sul site is a rocky cliff that falls vertically down to $42 \mathrm{~m}$ deep, with an area of negative inclination between 12 and $27 \mathrm{~m}$, from the center of the formation to the east (FUNDAÇÃO FLORESTAL, 2013). It is also more affected by waves than the Portinho site. For these reasons, this site is frequented by divers with advanced certification.

\section{Field Methods}

In this study two different types of campaign were conducted during the period of July 2013 and June 2015: land based surveys (bimonthly) and nocturnal dives (biannual). The choice of the land based survey method was made after no sea turtles were observed during an exploratory campaign on board a vessel in June 7th, 2013.

\section{LAND BASEd SuRVEYS}

The land based survey consisted of visual observations during day time from two different sites on the Laje de Santos Island, aiming at a quantitative survey of the animals present at each site. The two sites were designated Paredão da Face Sul and Portinho (Figure 2). The observations were made simultaneously by two trained observers.

The campaigns for the land based surveys were schemed to occur every two months, but due to weather and sea conditions some had to be postponed, thus increasing this interval. Each campaign was carried out in one day, during day time, and at least 4 observations of 15 minute each, with intervals of $5 \mathrm{~min}$ between them for rest, were made in this period. When the weather and logistic conditions allowed, more observations were made. Weather conditions, time of the beginning and end of the observations and other relevant information were logged.

To record each observation, a spreadsheet with the columns "Heads" and "Turtles" was used. Each time the head of a turtle was seen, that observation was registered in the "Heads" column, even if the same animal showed its head twice (and so two-head observations were counted) (Figure $3 \mathrm{~B})$. Counting the number of heads does not allow one to know how many turtles appeared at the site, it does, however, provide the frequency of the sightings of these animals. In the "Turtle" column, the number of animals seen at the same time in a group was recorded (Figure 3A). This number is closer to the real number of animals in the water. It is, further, possible that there were more animals underwater, appearing at different moments during the observation period, that may have been accounted as just one.

The method of land based survey has its limitations since is not possible to quantify how many marine turtles are actually in the water. However, this method has a lower cost compared to diving surveys and even so provides information about the presence and frequency of the turtles at that site. 


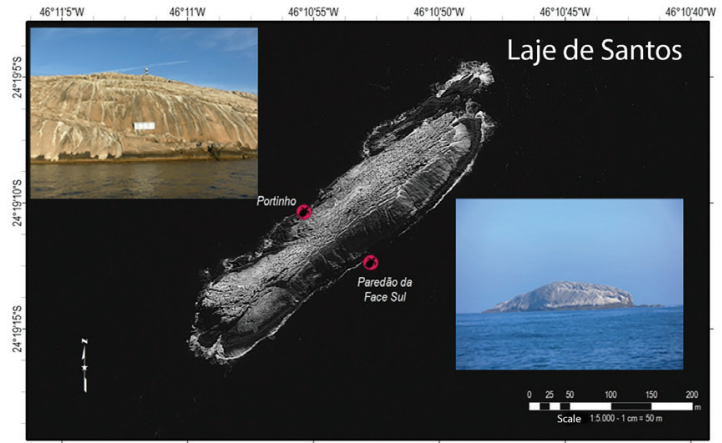

Figure 2. Location of the fixed points, Portinho and Paredão da Face Sul, from which sea turtle observations were undertaken on the Laje de Santos (Photos by Ana Carolina Luchetta).

Another limitation with this method of observation is that it depends more on the training and experience of the observer, which may lead to less accuracy and precision.

\section{NOCTURNAL DIVES}

One nocturnal dive was conducted in July $30^{\text {th }} 2013$, February $4^{\text {th }} 2014$, September $2^{\text {nd }} 2014$ and May $20^{\text {th }} 2015$. The nocturnal dives sought to capture the animals during their rest period, take biometry measurements, photograph, tag and then release them. The presence of epibionts and the overall health condition of the sea turtles, especially the presence of fibropapilloma, were also observed. In the nocturnal dives, the sea turtles were located resting at the Portinho site at approximately $12 \mathrm{~m}$ depth by our team of SCUBA divers. They captured the resting turtles and brought them manually with care on board to take biometry data and a photographic record of each animal (Figure 4A). The animals were weighed on a hook scale with a precision of $0.5 \mathrm{~kg}$. The measurements of the curved carapace length (CCL) and the curved carapace width $(\mathrm{CCW})$ were taken using a tapemeasure. The CCL was measured from the anterior point of the precentral scute to the posterior tip of the postcentral scute (Figure 4C) and the $\mathrm{CCW}$ was taken at the widest part of the carapace, thus giving the greatest distance between the corresponding marginal scutes (Figure 4B) (BOLTEN, 1999).

A form was filled in for each animal captured with the following information: date, time, CCL, CCW, weight, presence of epibionts, parasites, fibropapillomas and injuries and tag number (if present). During the campaigns of September 2014 and May 2015, the unmarked sea turtles captured were tagged with stainless steel Inconel tags, model \#1005-681, of the National Band and Tag
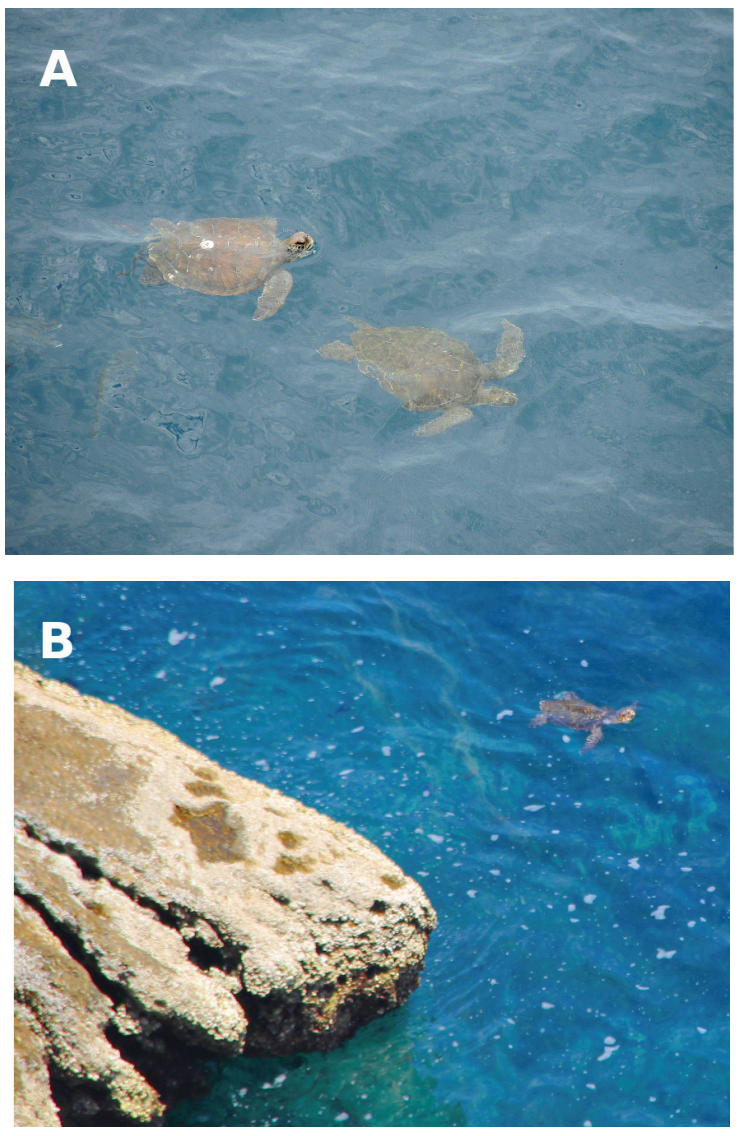

Figura 3. Examples of the observation of (A) two turtles and (B) one head at the Portinho site (Photo by Ana Carolina Luchetta and Gabriel Raposo).

Co., before release and the number of the tag was registered on the animal's form. The tags were provided by the TAMAR-ICMBio program and applied according to the guide-lines of the program: each animal must have a tag on each front flipper and when that is not possible, the tag must be applied on the rear flipper with an observation in the animal's file according to the manual for nonreproductive records for intentional capture of 2014 and the protocol for tagging and biometrics of marine turtles.

Photos of the carapace of each marine turtle captured, both sides of its head, any atypical condition such as carapace defects, tumors, injuries, etc., were taken to compose a photographic record and complement the information filled in on the forms.

In order to avoid the capture of the same animal twice or more during the surveys, first all the sea turtles were captured and only then they were released as the measurements were taken from. The release of the marine turtle occurred close to the place where it was captured to minimize stress. 


\section{RESULTS}

\section{LAND BASED SuRVEys ObSERVATIONS}

A total of $17015 \mathrm{~min}$. observations were made and only during 47 of them turtle no sea turtle observed. Sea turtles were observed on the 11 campaigns from both the fixed sites on the Laje de Santos Island (Table 1; Figure 5).
Although the method of land based observation does not allow the quantification of the marine turtles that are actually in the water, the results of the present study increased our knowledge of these animals in the Laje de Santos area. For example, it was possible to observe that the sea turtles are present in the Laje de Santos area throughout the year and at both sites.

Table 1. Date and total observation time of each land based survey and number of heads and turtles (total and per 15 min) observed at the two fixed sites on the Laje de Santos Island.

\begin{tabular}{|c|c|c|c|c|c|c|c|}
\hline Campaign & Date & Observation point & $\begin{array}{l}\text { Total time of } \\
\text { observation } \\
\text { (h) }\end{array}$ & $\begin{array}{l}\text { Total number } \\
\text { of heads }\end{array}$ & $\begin{array}{c}\mathrm{n}^{\circ} \text { heads/ } \\
15 \mathrm{~min}\end{array}$ & $\begin{array}{c}\text { Total number } \\
\text { of turtles }\end{array}$ & $\begin{array}{c}\mathrm{n}^{\circ} \text { turtles/ } \\
15 \mathrm{~min}\end{array}$ \\
\hline 1 & $30 / 07 / 2013$ & Portinho & 1.55 & 3 & 0.88 & 3 & 0.75 \\
\hline 1 & $30 / 07 / 2013$ & Paredão da Face Sul & 1.55 & 5 & 2.63 & 2 & 0.38 \\
\hline 2 & $27 / 11 / 2013$ & Portinho & 1.50 & 9 & 5.80 & 5 & 3.40 \\
\hline 2 & $27 / 11 / 2013$ & Paredão da Face Sul & 2.20 & 11 & 2.63 & 5 & 1.63 \\
\hline 3 & $04 / 02 / 2014$ & Portinho & 1.00 & 35 & 17.50 & 14 & 7.75 \\
\hline 3 & $04 / 02 / 2014$ & Paredão da Face Sul & 1.20 & 15 & 10.80 & 6 & 4.80 \\
\hline 4 & $01 / 04 / 2014$ & Portinho & 2.55 & 2 & 0.78 & 2 & 0.67 \\
\hline 4 & $01 / 04 / 2014$ & Paredão da Face Sul & 2.56 & 16 & 12.25 & 9 & 7.50 \\
\hline 5 & $05 / 06 / 2014$ & Portinho & 2.00 & 2 & 0.71 & 2 & 0.71 \\
\hline 5 & $05 / 06 / 2014$ & Paredão da Face Sul & 1.43 & 3 & 1.33 & 2 & 1.00 \\
\hline 6 & $02 / 09 / 2014$ & Portinho & 2.34 & 1 & 0.11 & 1 & 0.11 \\
\hline 6 & $02 / 09 / 2014$ & Paredão da Face Sul & 2.50 & 6 & 1.90 & 5 & 1.60 \\
\hline 7 & $30 / 09 / 2014$ & Portinho & 3.55 & 2 & 0.42 & 2 & 0.42 \\
\hline 7 & $30 / 09 / 2014$ & Paredão da Face Sul & 3.36 & 6 & 3.27 & 3 & 1.91 \\
\hline 8 & $12 / 12 / 2014$ & Portinho & 2.00 & 10 & 4.43 & 4 & 2.57 \\
\hline 8 & $12 / 12 / 2014$ & Paredão da Face Sul & 1.41 & 13 & 10.67 & 7 & 5.33 \\
\hline 9 & $28 / 01 / 2015$ & Portinho & 1.35 & 1 & 0.33 & 1 & 0.33 \\
\hline 9 & $28 / 01 / 2015$ & Paredão da Face Sul & 1.22 & 15 & 10.80 & 9 & 6.40 \\
\hline 10 & $14 / 04 / 2015$ & Portinho & 2.00 & 3 & 1.29 & 2 & 1.00 \\
\hline 10 & $14 / 04 / 2015$ & Paredão da Face Sul & 2.10 & 5 & 2.00 & 4 & 1.75 \\
\hline 11 & $17 / 06 / 2015$ & Portinho & 3.05 & 3 & 1.40 & 3 & 1.10 \\
\hline 11 & $17 / 06 / 2015$ & Paredão da Face Sul & 3.25 & 6 & 2.73 & 4 & 1.45 \\
\hline
\end{tabular}

Most of the observations occurred under sunny conditions as on campaigns 1, 2, 3, 4, 8 and 9 (Table 2). During campaign 4 , despite the high sun, the clouds and constant wind made the weather more pleasant, allowing a longer observation time. In this campaign, three observations of a turtle of similar size were made in the same place. The observer was able to assume that it was the same individual, because the visibility was enhanced due to the weather conditions. 


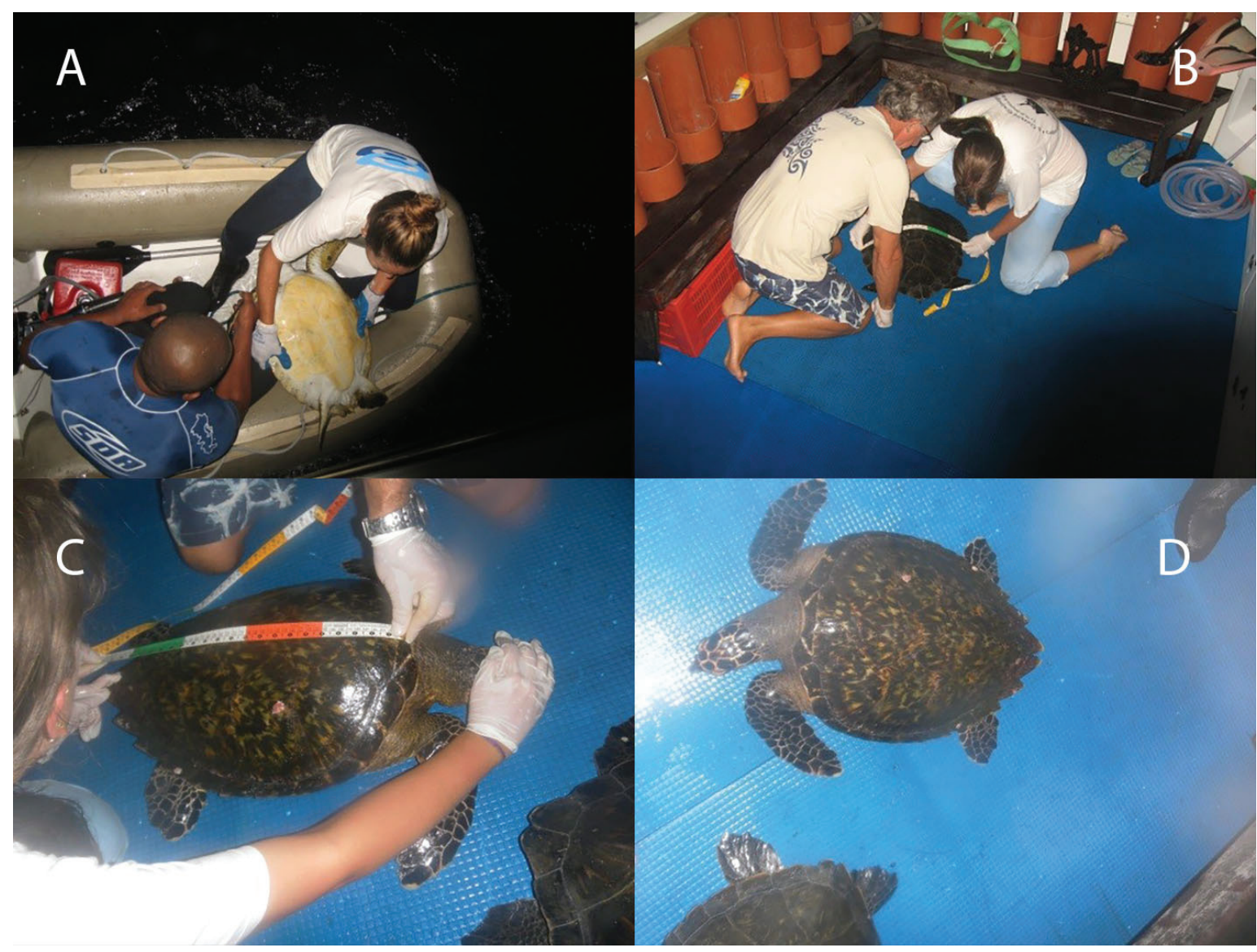

Figure 4. Marine turtle captured during a nocturnal survey. A) animal captured and taken on board; B) measurement of the $\mathrm{CCW}$; C) measurement of the CCL, and D) animal ready to be released (Photos by Ana Carolina Luchetta).

Table 2. Weather condition (cloud coverage and wind speed) during each campaign for the land based surveys on the Laje de Santos Island.

\begin{tabular}{|c|c|c|c|c|c|c|}
\hline \multirow{2}{*}{ 泀 } & \multicolumn{3}{|c|}{ Cloud coverage } & \multicolumn{3}{|c|}{ Wind } \\
\hline & $\begin{array}{c}\text { Clear Sky } \\
\text { (sunny) }\end{array}$ & $\begin{array}{c}\text { Partially } \\
\text { Cloudy }\end{array}$ & $\begin{array}{c}\text { Clou- } \\
\text { dy }\end{array}$ & Light & $\begin{array}{l}\text { Mo- } \\
\text { de- } \\
\text { rate }\end{array}$ & Strong \\
\hline 1 & & $\mathrm{X}$ & & $\mathrm{X}$ & & \\
\hline 2 & & $\mathrm{X}$ & & & $\mathrm{X}$ & \\
\hline 3 & $\mathrm{X}$ & & & $\mathrm{X}$ & & \\
\hline 4 & & $\mathrm{X}$ & & $\mathrm{X}$ & & \\
\hline 5 & & & $\mathrm{X}$ & & $\mathrm{X}$ & \\
\hline 6 & & & $\mathrm{X}$ & & & $\mathrm{X}$ \\
\hline 7 & & & $\mathrm{X}$ & & & $\mathrm{X}$ \\
\hline 8 & & $\mathrm{X}$ & & $\mathrm{X}$ & & \\
\hline 9 & $X$ & & & $\mathrm{X}$ & & \\
\hline 10 & & & $\mathrm{X}$ & & & $\mathrm{X}$ \\
\hline 11 & & & $\mathrm{X}$ & $\mathrm{X}$ & & \\
\hline
\end{tabular}

Campaign 9 had its total observation time reduced due to the heat and absence of wind. However, the lack of wind made the surface of the water calmer, which facilitated the observations, even allowing the sighting of a tagged turtle at the Paredão da Face Sul site. Here it is important to emphasize that we cannot assert that the others turtles observed were not tagged, since this observation occurred on a day with exceptionally favorable sighting condition. On campaign 11 (June 2015) in this same site, although it was cloudy, the absence of wind improved the observation and allowed the identification of a specimen as being a hawksbill turtle. The opposite occurred on campaign 6 , when the weather had sunny and cloudy periods, with a wind making the surface of the sea rougher, which made observation more difficult. Even so, it was possible to see a group of two bigger and three smaller turtles swimming together for a long time at the Paredão da Face Sul site.

The longest total observation time occurred on the cloudy days, as on campaigns 7 (when the sea was also 


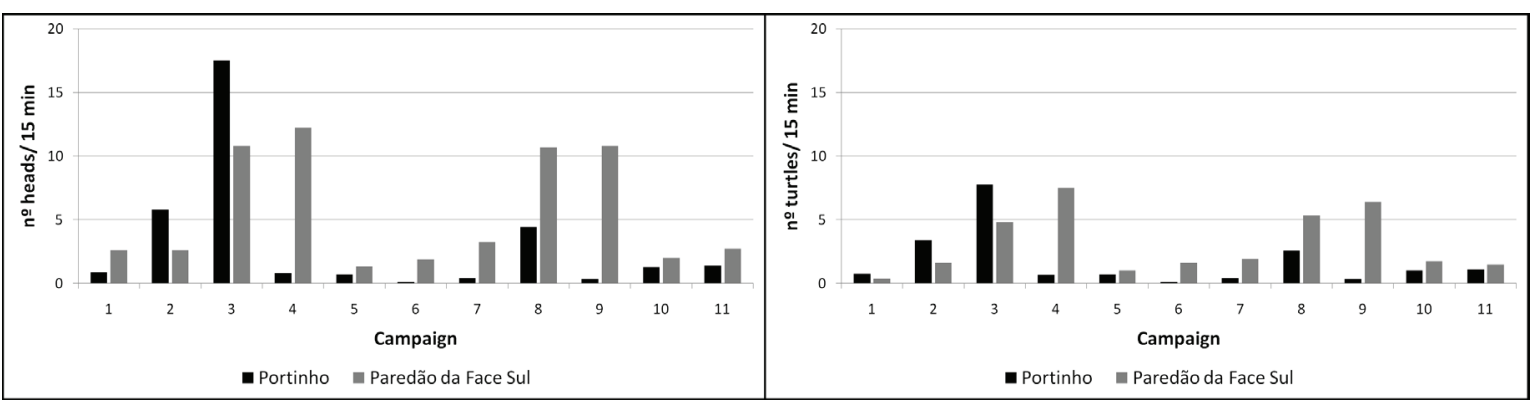

Figure 5. Frequency of sightings ( $\mathrm{n}^{\mathrm{o}}$ heads $/ \mathrm{min}$ ) and approximate number of individuals $\left(\mathrm{n}^{\mathrm{o}}\right.$ turtles $\left./ 15 \mathrm{~min}\right)$ obtained in the campaigns at each fixed point on the Laje de Santos Island.

rough due to the wind), 10 and 11 . Campaign 5, although it occurred on a cloudy day, consisted of only 2 hours of observation for reasons of safety, as rain threatened.

In general, considering the eleven campaigns, the Paredão da Face Sul site presented a higher number of heads (mean of 5.55 heads/15 min) and turtles (mean 3.07 turtles/15 min) per 15 min than the Portinho site (mean of 3.06 heads $/ 15 \mathrm{~min}$ and 1.71 turtles $/ 15 \mathrm{~min}$ ). As for the variations throughout the year, in the campaigns conducted during the wintertime (campaigns 1 and 6), the numbers of heads and turtles were smaller (a maximum of 5 and 6 , respectively). The mean frequency of sightings for both sites was of 1.38 and the approximate number of individuals was of 0.71 for the two sites. In the surveys that occurred during springtime (campaigns 2, 7 and 8), the number of animals observed increased to 7 turtles and 13 heads, with a mean frequency of sighting for both sites of 4.54 and an approximate number of individuals of 2.54 .
During the campaigns carried out in summer (campaigns 3 and 9), the mean value of heads and turtles observed was of 9.86 and 4.82, respectively. Lastly, the absence or the observation of just one individual was frequent in the campaigns conducted during autumn (campaigns 4, 5, 10 and 11), with the exception of the sighting of the 16 heads and 9 turtles at the Paredão da Face Sul site during campaign 4. The mean frequency of sighting was 2.81 and the mean approximate number of individuals was 1.90 .

\section{NOCTURNAL DIVES}

Four nocturnal dives were conducted in this study in July 2013, February and September 2014, and May 2015. In these four campaigns, two species were captured: green turtle (Chelonia mydas) and hawksbill turtle (Eretmochelys imbricata). The data obtained from the turtles captured during the surveys are summarized in tables 3 for the green turtles and 4 for the hawksbill turtles.

Table 3. Biometry (range and mean \pm standard deviation) and percentage of individuals tagged, with presence of epibionts, papilloma and deformities/injuries of the green turtles (Chelonia mydas) captured during the nocturnal surveys on the Laje de Santos Island $(\mathrm{n}=37)$.

\begin{tabular}{|c|c|c|c|c|c|c|c|c|c|c|}
\hline \multirow{2}{*}{ 莡 } & \multicolumn{2}{|c|}{$\operatorname{CCL}(\mathrm{cm})$} & \multicolumn{2}{|c|}{ Weight (kg) } & \multicolumn{2}{|c|}{ Tags } & \multirow[b]{2}{*}{$\begin{array}{c}\text { Epibionts } \\
(\%)\end{array}$} & \multirow[b]{2}{*}{$\begin{array}{l}\text { Papillo- } \\
\text { ma (\%) }\end{array}$} & \multirow[b]{2}{*}{$\begin{array}{l}\text { Deformities/ } \\
\text { injuries }(\%)\end{array}$} & \multirow[b]{2}{*}{ Total } \\
\hline & Range & Mean \pm DP & Range & Mean $\pm D P$ & $\begin{array}{c}\text { Previous } \\
(\%)\end{array}$ & $\begin{array}{c}\text { Applied } \\
(\%)\end{array}$ & & & & \\
\hline 1 & $38.0-61.0$ & $51.3 \pm 10.1$ & $6.0-25.0$ & $17.2 \pm 9.0$ & 0 & 0 & 0 & 0 & 16.7 & 6 \\
\hline 2 & $44.0-65,0$ & $54.0 \pm 7.2$ & $9.8-32.0$ & $19.7 \pm 7.7$ & 0 & 0 & 0 & 0 & 0 & 6 \\
\hline 3 & $47.0-65.0$ & $56.1 \pm 5.4$ & $12.4-32.5$ & $21.3 \pm 5.9$ & 0 & 100 & 11.1 & 11.1 & 44.4 & 9 \\
\hline 4 & $39.0-66.5$ & $53.4 \pm 9.4$ & $7.0-34.5$ & $19.3 \pm 10.1$ & 12.5 & 87.5 & 6.2 & 6.2 & 25 & 16 \\
\hline
\end{tabular}


Table 4. Biometry (range and mean \pm standard deviation) and percentage of individuals tagged, with presence of epibionts, papilloma and deformities/injuries of the hawksbill turtles (Eretmochelys imbricata) captured during the nocturnal surveys on the Laje de Santos Island $(\mathrm{n}=4)$.

\begin{tabular}{|c|c|c|c|c|c|c|c|c|c|c|}
\hline \multirow{2}{*}{ Uू } & \multicolumn{2}{|c|}{$\operatorname{CCL}(\mathrm{cm})$} & \multicolumn{2}{|c|}{ Weight (kg) } & \multicolumn{2}{|c|}{ Tags } & \multirow[b]{2}{*}{$\begin{array}{c}\text { Epibionts } \\
(\%)\end{array}$} & \multirow[b]{2}{*}{$\begin{array}{c}\text { Papilloma } \\
(\%)\end{array}$} & \multirow[b]{2}{*}{$\begin{array}{l}\text { Deformities/ } \\
\text { injuries (\%) }\end{array}$} & \multirow[b]{2}{*}{ Total } \\
\hline & Range & Mean \pm DP & Range & Mean \pm DP & $\begin{array}{c}\text { Previous } \\
(\%)\end{array}$ & $\begin{array}{c}\text { Applied } \\
(\%)\end{array}$ & & & & \\
\hline 1 & & & & & & & & & & 0 \\
\hline 2 & $45.0-45.0$ & & $10.8-10.8$ & & 0 & 0 & 100 & 0 & 0 & 1 \\
\hline 3 & $51.5-56.0$ & $53.8 \pm 3.2$ & $13.1-17.5$ & $15.3 \pm 3.1$ & 0 & 100 & 0 & 0 & 0 & 2 \\
\hline 4 & $55.5-55.5$ & & $18.5-18.5$ & & 100 & 0 & 0 & 100 & 0 & 1 \\
\hline
\end{tabular}

The first nocturnal survey started at dusk and six individuals of the green turtle (Chelonia mydas) were captured. One of them had a superficial injury in its carapace (Figure 6A). Due to technical problems, two specimens of this campaign could not be weighed.

During the second nocturnal dive (February 2014), seven turtles were captured: six green turtles and one hawksbill turtle (Eretmochelys imbricata). The captured hawksbill had many algae on its carapace. The other animal did not present any epibionts.

Tags provided by the TAMAR project were only available for the September 2014 and May 2015 campaigns. In September, twelve turtles were captured and tagged, two of them were hawksbill turtles and the others green turtles. Only one presented tumors and the others were healthy. One of the individuals had a deformity of the carapace (Figure 6B).

During the May 2015 campaign, 17 individuals were captured, three of them already tagged. Two of the recaptured turtles had been tagged by our team during the previous survey. The third animal, a C. mydas specimen, had not been marked by our team and it had just one tag on the right flipper, partially covered by algae, on which it was only possible to read the number 52311 (Figure 6C). In 2007, an individual of the same species was marked by TAMAR with the tag BR 52311. Although it was not possible to read the initial BR on the tag, it is very likely that it was the same animal since the same combination of numbers in another country is improbable. Only one turtle from this campaign presented small tumors in its soft tissues.

The specimens of $C$. mydas captured during this study presented CCL between 38.0 and $66.5 \mathrm{~cm}$ and weight between 6.0 and $34.5 \mathrm{~kg}$, which characterizes them as juveniles (ZUG \& GLQR, 1998) (Table 3). The E. imbricata were also juveniles, as their CCL ranged from 45.0 to $56.0 \mathrm{~cm}$ and their weight varied from 10.8 to $18 . \mathrm{kg}$ (LIMPUS, 1992) (Table 4).
Although the CCW data were collected, only the CCL is used to describe an individual; the $\mathrm{CCW}$ is, therefore, not shown.
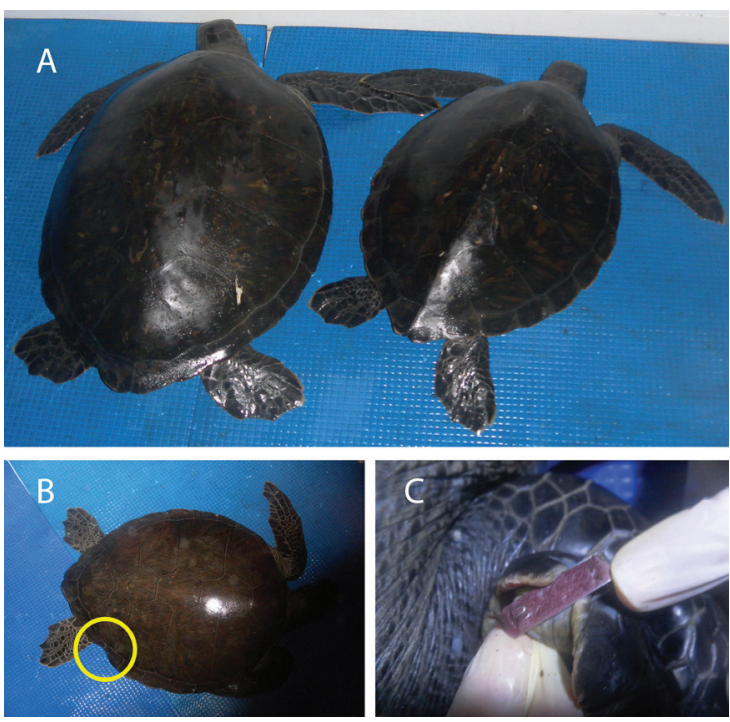

Figure 6. Sea turtles captured during the nocturnal campaigns. A) individual with a superficial injury (on the left) and another with no injury (on the right); B) Specimen with a defect in its carapace; C) Tag covered by algae impeding the visualization of its number (Photos by Ana Carolina Luchetta and Gabriel Raposo).

\section{DISCUSSION}

Despite the differences of the substrate and exposure to currents and winds between the Portinho e Paredão da Face Sul sites, both were suitable for the sighting of sea turtles, as the water visibility was good and it was even possible to see the details of the animals when the sea was calm. During the September 2014 survey, at the Portinho site, it was possible to continue to see the sea turtle even 
when submerged. The Paredão da Face Sul site is more exposed than the Portinho site to winds that disturb the sea's surface and hinder observation. However, even on windy days as on campaign 2, 5, 6, 7 and 10, the animals could still be clearly seen.

Considering the eleven campaigns, the Paredão da Face Sul site presented a higher number of heads/15 min (in nine campaigns) and turtles/15 min (in eight campaigns) than Portinho site (Figure 5). The higher number of heads could be explained by the rougher waters at this site that can lead the animals to surface more often to breathe or they might just be forced upwards by the strength of the currents. As for the number of turtles, the groups observed at the Paredão da Face Sul site were bigger and appeared over a wider area (even in areas far from any rocky formation). At the Portinho site, the groups were smaller and were always closer to a rocky formation.

During this study, two events deserve some attention. On campaign 3, the first group registered at the Portinho site was a group of 14 individuals (Figure 5). This number was probably overestimated since the observer was not experienced and the groups observed until that moment in this site were smaller. In order to avoid this mistake again, training was reinforced for the next observations. The other event occurred during campaign 4 , when a diving operation was underway at the Portinho site during the sighting activities. The Laje de Santos Island is a traditional diving site, especially in the Portinho site which is more frequented by divers than the Paredão da Face Sul. Still marine turtles are often reported by divers, thus it is plausible that these turtles are used to their presence. A study conducted in a protected marine area in Honduras observed that the marine turtles did not change its behavior when encountered divers (HAYES et al., 2016). However, it is possible that a large group of divers could have driven the marine turtles into deeper waters or momentarily away from the Portinho site as the number of observations in this occasion was lower when comparing with the Paredão da Face Sul site. In fact, a study held in Hawaii observed that marine turtle ran away from snorkelers (MEADOWS, 2004). This issue shows the importance of an in-water monitoring of the impacts of recreational diving on marine turtles to improve management strategies of the marine park. Baumbach et al. (2016) recommended that "management officials in marine protected areas (MPAs) around the world implement research projects using in-water observations and turtles sighting surveys to quantify the impact of recreational diving on different species of sea turtles".
The variation of the mean values of heads and turtles per minute over the seasons studied here showed that during autumn and wintertime this number was lower than during the spring and summertime. Sea turtles are reptiles and the environmental temperature influences the physiology of these animals, reducing their activity in cold water. If the temperature is too low for the turtle to survive in the active state, it can become dormant (MOON et al., 1997), which corroborates the lower number of observations made during the surveys conducted in winter. In laboratory experiments, it was also possible to verify changes in the respiratory frequency (breaths per minute) of green turtle with temperature. The animals in tanks with water above $15^{\circ} \mathrm{C}$ swam actively, while those in tanks with a lower temperature became very slow and remained at the bottom for long periods with little movement, rising to the surface to breath at intervals of up to three hours (MOON et al., 1997). It is not, therefore, possible to state that there are differences in the number of sea turtles depending on the season, but it is important to highlight that the observed differences can be attributed to water temperature. Despite campaign 4's having occurred at the beginning of the autumn, the day was hot, which may explain the higher number of heads and turtles observed.

Most of the animals observed during the land based surveys were resting (floating on the surface) and after a while they dived - probably in search of food. The Laje de Santos Marine State Park benthic habitat is mainly covered by zoanthids, hydrozoans, ascidians, octocorals, coral colonies of Madracis decactis and Mussismiliahispida (LUIZJUNIOR et al., 2008) and a rich and abundant seaweed flora (AMADO FILHO et al., 2006; JORGE et al., 2012) which all represent food for the marine turtles. Hence, it is possible to infer the Laje de Santos Island is used as a feeding and shelter area. Juveniles usually migrate from oceanic to neritic areas, where food is abundant, to complete their development (MUSICK \& LIMPUS, 1997).

Although the sea turtles observed off the Laje de Santos Island presented different sizes, they were all juveniles of C. mydas and E. imbricata. These two species were the same as those observed by TAMAR on islands of the São Paulo coast. Juveniles of E. imbricata are distributed all around the northern and northeastern Brazilian coast and are less frequent on the southern and southeastern coast (MARCOVALDI et al., 2011). On the other hand, juveniles of $C$. mydas are cosmopolitan and distributed along the whole of the Brazilian coast, transiting between different countries (ALMEIDA et al., 2011). This distribution 
pattern of these species corroborates the higher number of C. mydas captured in this study.

Although fibropapillomatosis can affect others species of turtles, only in C. mydas it has reached a panzootic status (WILLIAMS et al.,1994). In the present study, tumors were observed only in this specie. Nevertheless, of the 41 sea turtles captured during the nocturnal dives, only 2 of them $(4.9 \%$ of the total) presented tumors and even so they were small. The TAMAR project registered $15.4 \%$ of animals with tumors (of a total of 10170 animals captured) between 2000 and 2005 in Brazil and 10.7\% along the coast of the state of São Paulo. Of the 170 captured turtles in southeast Brazil, $44.1 \%$ had tumors of varying degrees of severity (SANTOS et al., 2015). Fibropapillomatosis has been observed more frequently in juveniles of $C$. mydas (WILLIAMS, 1994; AGUIRRE et al., 1998) with carapace length of 40 to $90 \mathrm{~cm}$ and weight between 10 and $30 \mathrm{~kg}$ (GEORGE, 1997), as were the animals captured in this study. No hawksbill turtles captured presented fibropapillomatosis both in the present study as well as in one conducted in the state of Paraíba, northeastern coast of Brazil (MASCARENHAS; IVERSON, 2008). All this information can be relevant for studies of this disease and its correlation with environmental factors. However, it is still necessary to increase the number of animals captured in order to obtain a more reliable correlation.

The measurements obtained of the $C$. mydas captured on the Laje de Santos Island are similar to those obtained by other studies conducted on the Brazilian coast (Table 5), with a mean CCL value very close to that observed in the Arvoredo Marine Biological Reserve. The same occurred with the species E. imbricata (Table 6). This species can be found along the whole of the Brazilian coast, but less frequently than other species (GALLO et al., 2006), as was observed in this study.

Table 5. Biometric data of $C$. mydas captured on the Brazilian coast. CCL $=$ curved carapace length $(\mathrm{cm})$.

\begin{tabular}{llll}
\hline \multicolumn{1}{c}{ Location } & \multicolumn{1}{c}{ CCL range } & mean CCL & \multicolumn{1}{c}{ Reference } \\
\hline Ceará $(\mathrm{n}=2)$ & $34.3-39.7$ & 37.0 & Lima et al., 2010 \\
Ubatuba $(\mathrm{n}=2254)$ & $27.0-96.0$ & 40.6 & Gallo et al., 2006 \\
Arvoredo Marine Biological Reserve $(\mathrm{n}=157)$ & $32.0-83.0$ & 50.1 & Reisser et al., 2008 \\
Atol das Rocas $(\mathrm{n}=386)$ & $29.5-86.0$ & 48.0 & Grossman et al., 2007 \\
Laje de Santos $(\mathbf{n}=\mathbf{3 7})$ & $\mathbf{3 8 . 0}-\mathbf{6 6 . 5}$ & $\mathbf{5 3 . 8}$ & This study \\
\hline
\end{tabular}

Table 6. Biometric data of E. imbricata captured on the Brazilian coast. CCL $=$ curved carapace length (cm).

\begin{tabular}{llll}
\hline \multicolumn{1}{c}{ Location } & \multicolumn{1}{c}{ CCL range } & mean CCL & \multicolumn{1}{c}{ Reference } \\
\hline Anchieta Island State Park $(\mathrm{n}=12)$ & $30.0-79.5$ & 46.4 & Leite et al., 2013 \\
Ceará $(\mathrm{n}=3)$ & $35.7-43.2$ & 39.3 & Lima et al., 2010 \\
Ubatuba $(\mathrm{n}=22)$ & $32.0-67.0$ & 46.1 & Gallo et al., 2006 \\
Arvoredo Marine Biological Reserve $(\mathrm{n}=6)$ & $36.0-59.6$ & 44.1 & Reisser et al., 2008 \\
Laje de Santos $(\mathbf{n}=\mathbf{4})$ & $\mathbf{4 5 . 0}-\mathbf{5 6 . 0}$ & $\mathbf{5 2 . 0}$ & This study \\
\hline
\end{tabular}

Of the three animals recaptured (with tags), two had been marked by this study during the previous campaign. Both the C. mydas and the E. imbricata recaptured presented an increase in size and weight (Figure 7). The green turtle had an increase in length of $1.5 \mathrm{~cm}$ and in weight of $6 \mathrm{~kg}$ after 8 months. In the same period, the hawksbill turtle increased $4 \mathrm{~cm}$ in length and $5.5 \mathrm{~kg}$ in weight. Their growth indicates that the Laje de Santos region is an important feeding area for the sea turtles. The continuity of this study will contribute to obtain more data and establish growth rates of the species.
The third recaptured animal was the one with the tag on which it was only possible to read the number 52311, presumed to be an individual of the $C$. mydas species marked by TAMAR with the tag BR 52311. When the TAMAR project team tagged this animal in 2007, it had a CCL of 47 $\mathrm{cm}$ and weight of $13.5 \mathrm{~kg}$. After 8 years, the turtle showed an increase of $18 \mathrm{~cm}$ in its CCL and $21 \mathrm{~kg}$ in its weight (Figure 7). It is not possible to affirm that this animal has stayed on the Laje de Santos Island all these years, since no systematic study of sea turtles has been made in the park 
during this period. However, because the park has an abundance of food, it is favorable place for a long stay.

As sea turtles have a long life span, continued monitoring is required to assess the importance to them of the PEMLS. Nevertheless, data from these two years of monitoring indicated that the park is used throughout the year by sea turtles, especially by C. mydas and E. imbricata, as a feeding area. Besides that, it will soon be possible to verify the destination of the animals that leave the park through the recapture of the tagged turtles by other researchers. The results of this study have proved the importance of the PEMLS to the marine turtles. The conservation of this area is, therefore, essential to these and other organisms.

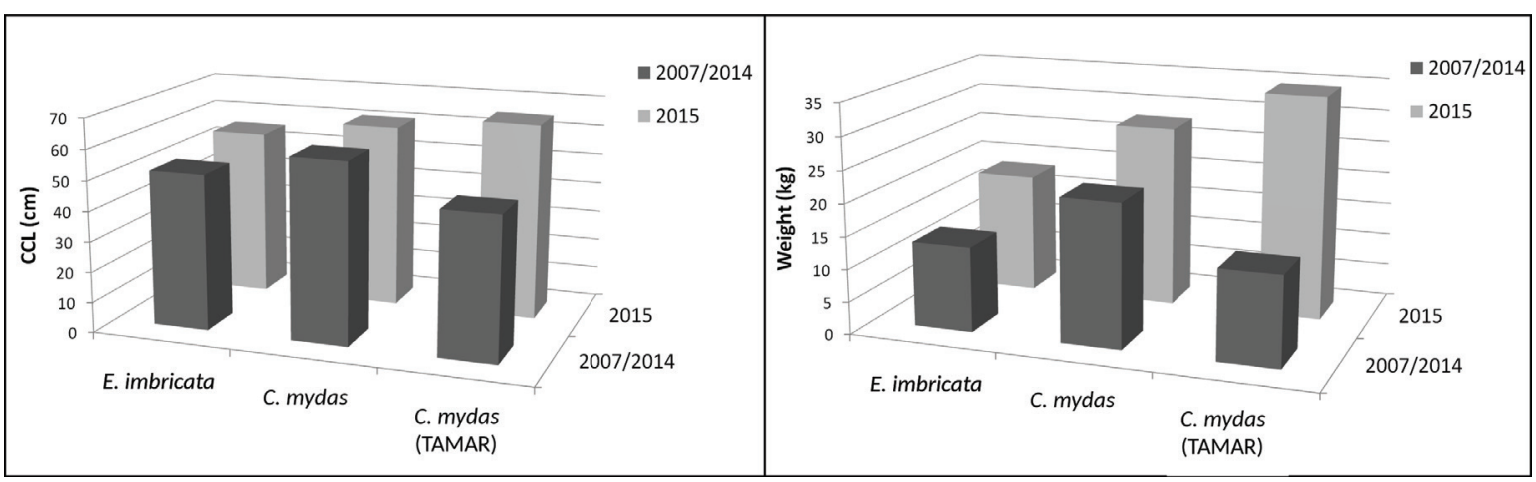

Figure 7. Measurements (CCL and weight) of the sea turtles when they were tagged (2007/2014) and when they were recaptured (2015).

\section{ACKNOWLEDGEMENTS}

We wish to thank PETROBRAS for their financial support for this project and FUNDESPA for their assistance with the logistics and the campaigns. We would also thank the divers, without whom we would have been unable to achieve the objective of this study and the Fundação Florestal, who ensured our safety during the boarding and landing. Our gratitude is also due to everyone who helped us at some stage of this study.

\section{REFERENCES}

ABESSA, D. M. S.; OBERG, I. M. F. ; PELLEGRINI, S. O. P.; BARBOSA, F. P.; ROCHA, F.; SANTANA, C. R.; MALIMPENSA, R. F.; CAMARGO, F. B. F.; SILVA, L. A.; OLIVEIRA, A. R. 2005. Identificação e Quantificação das Espécies de Tartarugas Marinhas da Baía de São Vicente, SP, Brasil (Projeto TAR-ROCA). Technical Report. UNESP CLP/SV \& IBAMA. São Vicente, SP. 30p. + anexos.

ABESSA, D. M. S.; BARBOSA, F. P.; ROCHA, F.; NASCIMENTO, R. F. F. 2007. Ocorrência de Tartarugas Marinhas na Baía de São Vicente, SP, Brasil. Technical Report (MPE, referring to the Civil Inquiry $\left.\mathrm{N}^{\circ} 014 / 02-\mathrm{MA}\right)$. UNESP CLP. São Vicente, SP. 39p.

AGUIRRE A.A, SPRAKER, T.R.; BALAZS, G.H., ZIMMERMAN, B. 1998. Spirorchidiasis and fibropapillomatosis in green turtles from the Hawaiian Islands Journal of Wildlife Diseases 34 (1), 91-98.
ALMEIDA, A. P.; SANTOS, A. J. B.; THOMÉ, J. C. A.; BELINI, C.; BAPTISTOTTE, C.; MARCOVALDI, M. A.; SANTOS, A. S.; LOPEZ, M. 2011. Avaliação do Estado de Conservação da Tartaruga Marinha Chelonia mydas (Linnaeus, 1758) no Brasil. Biodiversidade Brasileira, Ano 1 - No 1, p. 12-19.

AMADO FILHO, G. M.; HORTA, P. A.; BRASILEIRO, P. S.; BARROS-BARRETO, M. B.; FUJII, M. T. 2006. Subtidal benthic marine algae of the Marine State Park of Laje de Santos (São Paulo, Brazil). Braz. j. oceanogr., São Paulo, v. 54, n. 4 , p. $225-234$.

AWABDI, R. D.; SICILIANO, S.; DI BENEDITTO, A. P. M. 2013. Ingestão de resíduos sólidos por tartarugas-verdes juvenis, Chelonia mydas (L.1758), na costa Leste do Estado do Rio de Janeiro, Brasil. Biotemas, 26(1).

BOLTEN, A. C. 1999. Techniques for Measuring Sea Turtles. In: ECKERT, K. L.; BJORNDAL, K. A.; ABREU-GROBOIS, F. A. \& DONNELLY, M. eds. Research and Management Techniques for the Conservation of Sea Turtles. Pennsylvania, IUCN/SSC Marine Turtle Specialist Group. 248p.

FUNDAÇÃO FLORESTAL, 2013. Plano Emergencial de Uso Público - Parque Estadual Marinho da Laje de Santos. Available in: http://fflorestal.sp.gov.br/files/2014/04/Plano-Emergencial- de-Uso-P\%C3\%BAblico_PEMLS versaoFinal.pdf (accessed in November 2015).

GALLO, B. M. G.; MACEDO, S.; GIFFONI, B. B.; BECKER, J. H. \& BARATA,. P. C. R. 2006. Sea turtle conservation in Ubatuba, southeastern Brazil, a feeding area with incidental capture in coastal fisheries. Chelonian Conserv Biol, 5:93-101.

GEORGE, R.H. Health problems and diseases of sea turtle. In: MUSICK, J.A.; LUTZ, P.L. The biology of sea turtle. New York: Science series, 1997, p.364-375. 
HAYES, C. T.; BAUMBACH, D. S.; JUMA, D.; DUNBAR, S. G. 2016. Impacts of recreational diving on Hawksbill Sea Turtle (Eretmochelys imbricata) behaviour in a marine protected area. Journal of Sustainable Tourism 25:79-95.

IUCN 2016. The IUCN Red List of Threatened Species. Version 20161. $<\mathrm{http}: / /$ www.iucnredlist.org $>$. Downloaded on 30 June 2016.

JORGE, R. R.; HARARI, J.; FUJI, M. T. 2012. Macroalgal composition and its association with local hydrodynamics in the Laje de Santos Marine State Park, southwestern Atlantic, São Paulo, Brazil. Braz. j. oceanogr., São Paulo, v. 60, n. 3, p. 405-419.

LEITE, T. C.; BONDIOLI, A. C. V.; MARTINS, J. K.; RODRIGUES, J.; GUTIERREZ, D. 2013. Record of a hawksbill sea turtle (Eretmochelys imbricata, Linneaus 1766) aggregation at Anchieta Island State Park, Ubatuba, São Paulo, Brazil. Marine Turtle Newsletter 139:1-3.

LIMA, E. H., MELO, M. T. D., \& BARATA, P. C. 2010. Incidental capture of sea turtles by the lobster fishery off the Ceará coast, Brazil. Marine Turtle Newsletter, (128), 16.

LIMPUS, C. J. 1992. The hawksbill turtle, Eretmochelys imbricata, in Queensland: population structure within a southern Great Barrier Reef feeding ground. Wildl. Res., 19:489-505.

LUIZ, O. J.; CARVALHO-FILHO, A.; FERREIRA, C. E. L.; FLOETER, S. R.; GASPARINI, J. L.; SAZIMA, I. 2008 The reef fish assemblage of the Laje de Santos Marine State Park, Southwestern Atlantic: annotated checklist with comments on abundance, distribution, trophic structure, symbiotic associations, and conservation. Zootaxa 1807, 1-25.

MARCOVALDI, M. A., MARCOVALDI, G.G. 1999. Marine turtles of Brazil: the history and structure of Projeto TamarIbama. Biological Conservation, 91: 35-41

MARCOVALDI, M.A.; LOPEZ, G.L.; SANTOS, A.J.B.; BELLINIi, C.; SANTOS, A.S. \& LOPEZ, M. 2011. Avaliação do estado de conservação da tartaruga marinha Eretmochelys imbricata (Linnaeus, 1766) no Brasil. Biodiversidade Brasileira, 1: $20-27$

MÁRQUEZ, M.R. 1990. FAO species catalogue. Vol. 11: Sea Turtles of the world. An annotated and illustrated catalogue of sea turtle species known to date. FAO Fisheries synopsis No. 125, Vol. 11. Roma, FAO. 81p.

MASCARENHAS, R., IVERSON, P. J. 2008. Fibropapillomatosis in stranded green turtles (Chelonia mydas) in Paraiba State, Northeastern Brazil: evidence of a Brazilian epizootic? Marine Turtle Newsletter, vol. 120, p. 3-6.

MEADOWS, D. 2004 Behaviour of green sea turtles in the presence and absence of recreational snorkellers. Mar Turtle Newsl 103:1-4

MMA (MINISTÉRIO DO MEIO AMBIENTE) 2003 Instrução Normativa $n^{\circ}$ 3, de 27 de maio de 2003. Lista das espécies da fauna brasileira ameaçadas de extinção. Diário Oficial da República Federativa do Brasil, Brasília, 28 de maio de 2003.
MOON, D., MACKENZIE, D.S, OWENS, D.W. 1997. Simulated hibernation of sea turtles in the laboratory: I. Feeding, breathing frequency, blood $\mathrm{pH}$, and blood gases. Journal of Experimental Zoology, 278: 372-380.

MUSICK, J. A., LIMPUS, C. J. 1997. Habitat utilization and migration in juvenile sea turtles. Pages 137-164 in P. L. Lutz and J. A. Musick, editors. The biology of sea turtles. CRC Press, Boca Raton, Florida, USA.

REISSER, J., M. PROIETTI, P. KINAS, I. SAZIMA. 2008. Photographic identification of sea turtles: method description and validation, with an estimation of tag loss. Endangered Species Research, 5: 73-82.

SANTOS, M. R. D.; SILVA MARTINS, A.; BAPTISTOTTE, C.; WORK, T. M. 2015. Health condition of juvenile Chelonia mydas related to fibropapillomatosis in southeast Brazil. Dis Aquat Org 115:193-201.

SANTOS, R. G.; MARTINS, A. S.; TOREZANI, E.; BAPTISTOTTE, C.; DA NOBREGA, F. J.; HORTA, P. A.; WORK, T. M.; BALAZS, G. H. 2010. Relationship between fibropapillomatosis and environmental quality: a case study with Chelonia mydas off Brazil. Dis Aquat Org 89: 87-95

SÃO PAULO (ESTADO), 1993. Decreto $n^{\circ} 37537$ de criação do Parque Estadual Marinho da Laje de Santos. Secretaria de Meio Ambiente, 2p.

SAZIMA, I. \& SAZIMA, M. 1983. Aspectos de comportamento alimentar e dieta da tartaruga marinha, Chelonia mydas, no litoral norte paulista. Bolm Inst. oceanogr, S Paulo, 32(2): 199-203

STAMPAR, S.N., SILVA P.F., LUIZ J.J.O. 2007. Predation on the zoanthid Palythoa caribaeorum, (Anthozoa, Cnidaria) in southeastern Brazil. Marine Turtle Newsletter, 117:3-5.

UNEP-WCMC (Comps.) 2015. The Checklist of CITES Species Website. CITES Secretariat, Geneva, Switzerland. Compiled by UNEP-WCMC, Cambridge, UK. Available at: http:// checklist.cites.org. [Accessed (07/07/2016)].

WILLIAMS JR., E. H.; BUMKLEY-WILLIAMS, L.; PETERS, E. C.; PINTO-RODIGUEZ, B.; MATOS-MORALES, R.; MIGNUCCI-GIANNONI, A. A.; HALL, K. V.; RUEDAALMONACID, J. V.; SYBESMA, J.; DE CALVENTI, I. B.; BOULON, R. H. 1994. An epizootic of cutaneous fibropapillomas in green turtles Chelonia mydas of the Caribbean: part of a panzootic? Journal of Aquatic Animal Health 6:70-78.

ZUG, G. R., GLQR, R. E., 1998. Estimates of age and growth in a population of green sea turtles (Chelonia mydas) from the Indian River lagoon system, Florida: a skeletochronological analysis. Can. J. of Zoo., 76: 1497-1506. 